\title{
Resilience in Covid-19 Times - Is There a Plan B for the Future? A State of Art
}

\author{
Augusto Renato Pérez Mayo \\ PhD., Research Professor, Autonomous University from the State of Morelos \\ Nohemí Roque Nieto \\ PhD., Professor, Autonomous University from the State of Morelos \\ Fernando Romero Torres \\ PhD., Research Professor, Autonomous University from the State of Morelos \\ Felipe de Jesús Bonilla Sánchez \\ C. PhD., Professor, Autonomous University from the State of Morelos \\ Ana Elizabeth Salgado Arteaga \\ Universidad Autónoma del Estado de Morelos
}

\section{Abstract}

There are three concepts represented that prove the possibilities of finding a plan B for humankind towards a pandemic such as Covid-19. Our papers focus in the study for the prove of the organizational ambit in Mexico, where it hasn't been valued as a way of well-being to fortify people for a pandemic like Covid-19 in the organizations, that is to say, about which should be the Plan B for humankind, schools, universities, media, governments, and other domains. There is literature presented that provides arguments of an emergent and meaningful change in the paradigm of human evolution and other organization during future pandemics. To describe this change of strategy, we revisit Florentino, Ríos, Carrillo and Sacubo, Molina, Castello, Mikulic and Fernández, Palomar, Matus, Victorio among others. In any context where people are developed, they must confront situations that can affect significantly their life dynamics and lose forever the perception of a reality built over years of life, exposing them to risks on their physical, mental and emotional health. It is argued that the reason why organizations are not listening more, about the emergent sociocultural, economic, political, and even philosophical change that Covid-19 has caused. The general idea of a 
change on an emergent paradigm and the next step on the history of humankind is being hatched. ${ }^{1}$

Keywords: resilience, organizations, pandemic, emerging plan

\section{Introduction}

\section{Part I. The problem}

The concept of resilience ${ }^{2}$ according to diverse perspectives, seen by the Real Academy of the Spanish Language dictionary, comes from the latin word resilie -entis and means "to jump backwards, bounce, fall back" (RAE-ASALE, 2020). Garmezi (1991, p. 459), states that it is "the capacity to recover and maintain an adaptive sanity after being abandoned or the initial capacity to start a stressful event". Meanwhile Kotliarenco, Caceres and Fontecilla (1997), affirm that:

The focus of resilience comes from the premise of being born in poverty, like living in a physiologically insane environment; these are high risk conditions for the mental and physical health for people. Apart from focusing on circuits that maintain on this situation, resilience worries to observe those conditions that could possibly open to a more positive and sane development (1997, pp. 1-2).

It is also defined as "the human capacity of confronting, overcome and being strengthened or transformed by the experiences of adversity" (Amar Amar et al., 2013, p. 1). Flores Olvera (2014, p. 7) States that, it is "the potential capacity that an individual has to confront the adversity and keep growing form it". It also mentions that there exists a phenomenon opposite to resilience known as asiliente anomie that:

Is a sick attitude from the individual, a conduct deflected form policy, which characterizes mainly from transforming the real vision from itself, for a wrong vision that proves the incompetence of the individual and their social group to solve problems, to reach optimism and a high life standard, making them to obtain results that are negative to adversity (Flores Olvera, 2013, p. 7).

The current pandemic scenario in the world (2020), is a challenge and a threat to the human resistance process in every way: physical and mental. Is a threat for each eight dimensions: confronting, autonomy, self-esteem, awareness, responsibility, hope, sociability, tolerance and frustration. But, do all public and private organizations are

\footnotetext{
1 What is presented here is a state of the art that justifies the presentation of quotations and quotations, which are reflected in the paragraphs that precede or precede them.

2 It is about understanding and putting in due importance a concept of building the capacity for adaptation and recovery of the human being in adverse situations such as economic crises, emotional crises, as a consequence of the current pandemic; as a learning capacity, which should not be understood as a panacea but as an alternative.
} 
taking into consideration of these dimensions? Each one of these are a base of the resilient support of the human being towards these diverse situations.

\section{The problem}

In Mexico, there exists a total population of 126.2 million habitants (World Bank, 2018). according with data provided the $100 \%$ of Mexican population have never lived in a pandemic such as we are going through in June 2020, we have never been exposed to family context (house) labor (companies) where there are always contextual and individual problems presented (Maslach et al., 2001) joining the sanitary emergency, Covid-19.

In recent studies made June 21th 2020, the Health Secretary of Mexico states that: the quantity of cases in Mexico is 180,545 confirmed, 21,825 deaths (Health Secretary of Mexico, 2020) and in the world there are 8,860,331 confirmed positive cases and 465,740 deaths (WHO, 2020), and to this day there hasn't been fund a cure or the structural composition of the virus. The lack of investigators in Mexico is still precarious.

In this Covid-19 situation in many countries, such as Mexico, the answer was to send the population to quarantine and the strategy known as "sana distancia" as better tools to face it; quarantine has been used a long time ago as tool to prevent the possible spread of diseases transmissible among the population. (Barbisch et al., 2015).

However, we must consider if the benefits obtained with this mandatory is going to compensate the possible psychological cost during this period (Rubin \& Wessely, 2020). During the pandemic process there has not been a word about strategies to fortify resilience for the people.

During the period in which people are quarantined in their home, we can appreciate two types of reactions, in one way, it can bring the best of themselves, and in other way, it can present stress, burden and other physiological disorders. (Rubin \& Wessely, 2020).

In studies recently checked traumatic stress answers were measured in kids and fathers during pandemic disasters, it was found that these quarantine events can be traumatic, accomplishing the criteria to post-traumatic stress disorder. (TEPT) (Sprang \& Silman, 2013).

It is also important to mention that the economic decay probably will be a problem during quarantine, due to most of the population aren't allowed to work and have to interrupt their professional activities without a correct planning and their effects can last a long time. In other studies, the economic decay due to quarantine created several symptoms of distress, frustration and violence against the people surrounding each other (sons, wives, mothers and fathers (Pellecchia et al., 2015) and it has been reported as a risky factor for symptoms to physiological disorders, anger and anxiety, even months after the quarantine is ended (Mihashi et al., 2009). 
In other study based in the reaction of people in quarantine by the Ebola disease, it was found that, even when the participants were granted with an economic subvention, some of them felt that the quantity wasn't enough and/or came too late for them; due to this, many of them felt affected because they couldn't cover their current expenses. Many others became economically dependent from their families, generating the possibility of conflicts in this nature (Desclaux et al., 2017). The same thing Mexicans are passing though. This symptom probably happens because those with less income tend to be more affected to a temporal loss of income that those with a higher income. For this, employers should also consider proactive approaches that allow employees to work from home; this is to avoid economic loss and to maintain the proactivity and to be benefited from remote working of the employees.(Manuell \& Cukor, 2011).

In another study, psychological effects were studied from quarantined people in Toronto, Canada finding a high prevalence of psychological aguish. The symptoms of TETP and depression were found in the $28.9 \%$ and the $31.2 \%$ of surveyed people, respectively. Longer durations of quarantine were associated with a higher prevalence of symptoms of TEPT. Likewise, the knowledge or direct exposing to someone with a diagnosis of SARS was also associated with TEPT and depressive symptoms. (Hawryluck et al., 2004).

Also, in some reports of a study it is stated that negative psychological effects, including posttraumatic stress, confusion, and wrath symptoms. The stressful factors included mayor duration of the quarantine, fears of infection, frustration, boredom, inadequate supplies, incorrect information and financial loss (Bedford et al., 2020).

On the other side, on previous investigations, people who participated in them state that they perceive deficient information and sometimes deceit from authorities of public health and they turn it in a stress factor, believing that the information isn't sufficient and unclear to be able to take appropriate actions; such as, some habitants still don't get the purpose of the quarantine (Braunack-Mayer et al., 2013; Reynolds et al., 2008).

Finally, people also informed a perception of a lack of transparency from officer of health and government sectors about the gravity of the pandemic (Braunack-Mayer et al., 2013). Maybe due to the lack of clear patterns or justification for accomplishing quarantine protocols related to posttraumatic stress symptoms (Reynolds et al., 2008).

Negative psychological effects both in general population and personal health, that are those who are found in the first line of people who contracted this virus; the main symptoms are posttraumatic stress, confusion, and anger. Stressing factors include the enlargement of the quarantine, fears of infection, frustration, bad temper, aggressiveness, fatigue, boredom, inadequate supplies, incorrect information, and financial loss. 
Observing this problem from a scientific point of view, we have the perspective of Vincent Larivière, Fei Shu and Cassidy Sugimoto (march, 2020), who mention that important crisis tend to reveal hidden rules from the scientific system, making wellknown scientific practices public. The Coronavirus outbreak (COVID-19) in Mexico and the world, exposed an uncomfortable truth about science: The actual system of academic communication does not satisfy the need of science and society. More specifically, the crisis manifests two inferences in the investigation system: the predetermined value of closed science and the excessive focus on elite publishing, only in English, independently from the context and research consequences. For the case of Mexico, this is not distant, due to the collapsing of the political system, medical staff without knowledge and experience on the treatment of this disease made the sector to have $17 \%$ of infections between mayors, nurses, medics and even administrative staff and these, like a snowball, would infect their families and friends. In January 31 of 2020, Wellcome Trust reviewed coronavirus as an "important and urgent threat for global health" and asked for both magazine researchers and their sponsors to "make sure that the results of the investigation and relevant data for this outbreak were shared quickly and openly to inform to public health sectors and save lives". Partners from this declaration included mayor editorials, such as Elsevier, Springer Nature and Taylor \& Francis, such as, many other funders and social academies. Mixed partners of this statement were compromised to make all the investigations and data about the outbreak public immediately: on preprint repositories for articles that haven't been checked by pairs yet and on platforms of magazines for articles that that have been checked already (Carr, 2020).

This is a positive step, but it doesn't comes far enough to satisfy public needs, because the only thing it did, at least for Mexico, was to liberate and put a direct access to things that have nothing to do with the problem; and to be able to inform and cause awareness at least on people in the academic scope and work as expositors with collaborative tools to reach more citizens from the country or the world.

It is true that the documents and chapters from books that have been released for this action represent only a small proportion of literature available about Coronavirus. According to Web of Science (WOS), there have been 13,818 articles published about the Coronavirus topic since the final years of the decade of 1960. More than a half (51.5\%) of these articles have a restricted access. Coronavirus is without a doubt a great family of viruses and someone could argue the relevance of older researches on the actual outbreak. However, as an example, three documents about COVID-19 published on the edition of February 15th from The Lancer were based on 69 different documents indexed in WOS, which of $73.2 \%$ of them are mixed with 13,818 documents about Coronavirus. The most antique reference in these documents is from 1988; this remarks the fact that, even if Coronavirus can be a novelty, the research about Coronavirus is based on a long queue of literature of research that is often closed. 
The overlay of this scientific literature on larger investigation flows also highlights the limitations of this approach.

The 13,818 articles of coronavirus quote more than 200,000 articles, form virology to cancer and from public health to genetics and heritance (Figure 1). Less than a third of the quoted articles in which "coronavirus articles" obtained information and inspiration were other "coronavirus articles". Even if all the articles about coronavirus were available, this would not be enough to tackle the crisis, given the intrinsically interdisciplinary nature of the biomedical investigation. The base for the knowledge of the science is just much wider than only one topic. Seeing the literature through a wide lens about coronavirus articles causally related with COVID-19 only blinds the effort of the research for other work that could be crucial.

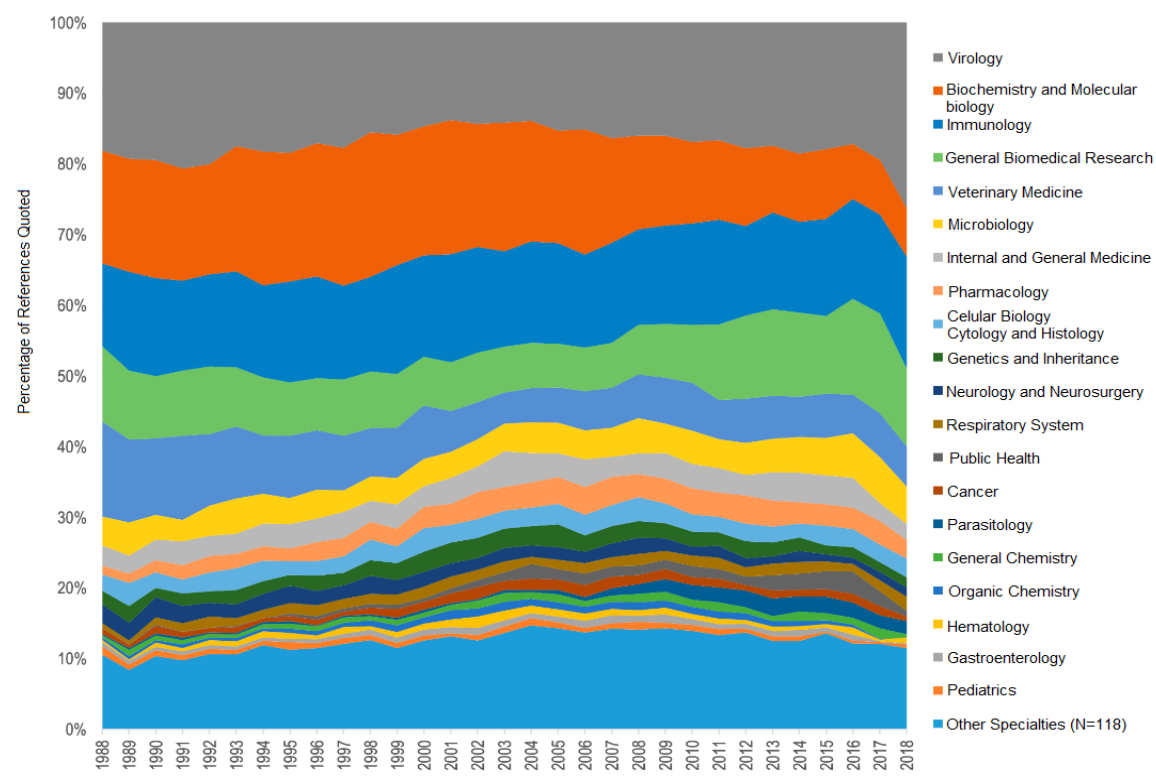

Figure 1. Percentage of references quoted by works about Coronavirus, by specialty of quoted magazines. Field NSF and subfield classification 1988-2018.

But this does not stop there; cures for deceases tend to come from new combinations and knowledge from several investigation areas. If the goal of opening an investigation is to advance in science and serve society, all the investigation must be open, not only a part of it. Not finding elements that allow human resource to heal the wound of losing its loved ones, besides the total confrontment conditions that has caused levels of interfamilial violence or against women or children in the world. The absence of resilience is total in all these articles.

Publication incentives are the other controversial element revealed by the actual outbreak. During the last decade, authorities and Chinese institutions, such as the ones in many other countries, have offered a financial direct reward based on the 
magazine in which researchers publish their work, with the implicit objective to put in a better position their institutions on international classifications. Invariably, publishing on these magazines implies to adjust to a frank language (English) and to publish about topics that matter to most of the guardians of these magazines that are disproportionately from western countries. Meanwhile, a larger diffusion to the scientific community is a more important objective; it should not be at the expense of diffusion to local communities, particularly to those who have a direct connection to the study scope. Due to the payment barriers and the use of English, international magazines tend to be inaccessible to those who are on the first global line of proposing medical attention and elaborating health norms, especially on crisis times. The only researchers that have possibilities of economic support to pay these articles are the ones on hard science and only a small group.

The actual outbreak exemplifies this efficiency. In late 2019, the Chinese Center for Control and Decease Prevention (CCDCP) sent a group of experts to Wuhan to recover data about the virus. This was almost three weeks after the first patient presented symptoms and right after the news of human-human transmission on social networks by eight different medics from Wuhan (posteriorly they were accused by police). Researchers analyzed data and the presented their results, including a verification of human-human virus transmission to high-prestige magazines from the west, such as The Lancet and The New England Journal of Medicine (NEJM), published on January 24th and 29th respectively. On January 20th it was published a public statement, recognizing the transmission form human to human.

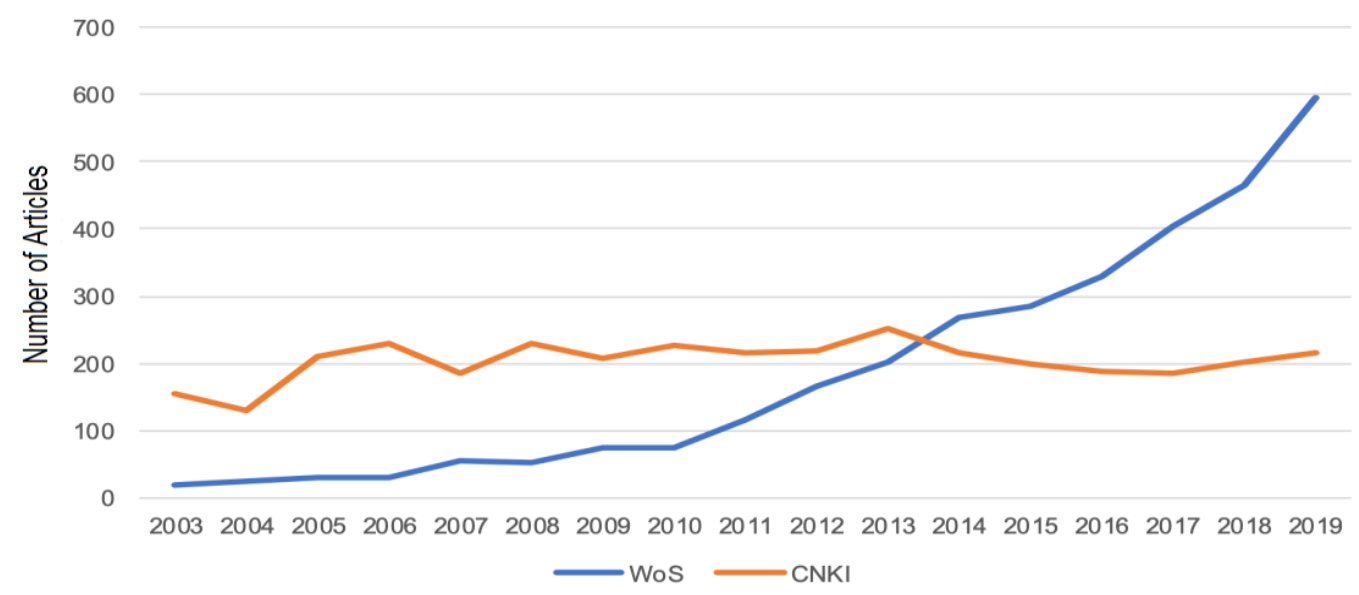

Figure 2. Number of articles about decease surveillance posted by Chinese investigators on international magazines (WOS) and on national magazines (CNKI). After the pandemic of SARS in 2003, the importance of the investigation about decease surveillance in China has exponentially increased 
In response to this, the Chinese government stipulated that financed projects about coronavirus, including the ones with new initiative $1.5 \mathrm{M}$ from the National Science Foundation of China (NSFC), should be published in local Chinese magazines instead of international ones and the emphasis should be for controlling the virus and saving lives. This suggests recognition from part of the Chinese government that the focus of publishing on elite magazines did not provide a convenient way of spreading results. Besides, the Ministry of Education (MoE) and Ministry of Science and Technology (MoST) emitted a mixed statement that required that universities and research institutions should limit the use of SCI documents, just like related indicators (for example, JIF, ESI, etc.) on investigation evaluation. MoST also stipulated that the number of documents cannot be used as key criteria for evaluating the development of the investigation and has prohibited the use of cash policies per publishing. All these initiatives point to a subjacent truth: prioritizing indicators about a sudden deliver for results to relevant communities is not the best for society.

Signatories to the declaration of agree to follow these principles not only for the actual outbreak, but also for every situation in the future "wherever there is a significant benefit for public health when guaranteeing that the data is shared in a quick and long way" (Carr, 2020). This statement establishes a direct link between public health and the trade of results for the investigation: explicitly arguing that walls and embargos from magazines are an obstacle for science and as a result they're a threat for public health. However, it also states the question: Where is the line of what constitutes a "public health benefit" drawn? In the last five months, the Center for Decease Control of the United States estimated that there was between 18,000 and 46,000 deaths related to the flu. Isn't there benefit for public health at doing public, or any type of research that can accelerate biomedical discovery and save lives? In Mexico it has been all the opposite, only financing is given for paying articles on international magazines that belong to the Scopus Sources y Master Journal List companies - WoS.

Es por ello por lo que hacemos un llamado a la comunidad científica (editores, financiadores y sociedades) para que se mantengan fieles a su palabra. It is necessary to quickly share the investigation to inform the public and save lives. We applause the job that it is being done through this crisis, we hope for this moment to serve as a catalyst for change. Trump's administration in the United States, for example, is considering an executive order that makes every financed study by the federal government to free to read at publishing. On the same way, the coalition of funders from the Plan S have been opposed by many of the signatories from the Wellcome Trust declaration. This is a blatant contradiction.

The signatories of the declaration from Wellcome Trust must extend their principles to cover all their practices: make the investigation to be available immediately and incentivize scientific communication to all the people who are interested. The scientific answer to Covid-19 has proven some of the benefits for opening the 
scientific system, including the torrent of documents that are shared immediately on preprint servers, the open collaboration and the discussion of scientist that use platforms such as social networks and the accelerated modeling of viral genomes. However, this would be in vane if the scientific system does not change. It is essential to recognize what is clear during these times of crisis: a robust scientific system and an informed citizenship requires immediate access and public to the research.

The review from the State of Art for the impact of Covid-19 does not show a resilient program at all as alternative, neither as plan B for future world pandemics. Fairly.

\section{Part ll. On why resilience as a key factor for the future of human resource towards a pandemic}

According to verified national and international investigations, resilience has been brought, but focused around kids, young people, and women in a situation of vulnerability, poverty, violence, and educational context, but not for phenomenon like pandemics, Covid-19. More recent studies focused around resilience have been accomplished on an international ambit with a quantity focus and a correlational scope.

Meneghel, Salanova and Martínez (2013), launch new study challenges of resilience in a labor context in which it remarks the necessity of studies with a focus on resilience at an organizational level, social level, group and individual. Therefore, the current investigation centers around contributing new discoveries that enrich previous works by other investigations focused on organizational resilience through the reinforcement of resilience on individuals, on institutions for future pandemics.

\section{Resilience as a key factor for future projects for human resources from global nations}

\section{Resilience background}

Studies of resilience appear around the 70's, their study isn't simple, due to the diversity of context, focuses, methodologies and several studies; but it is important to expand the knowledge about this phenomenon because it is actually primordial that human beings reinforce their capacities, resources and individual competences for confronting future world pandemics.

The conceptual study of resilience generated some attention and has been studied by several disciplines in the last years and decades, like the case of social and human sciences, therefore:

It is recognized as a valued perspective for its possible applications in the fields of health, prevention and education; as well as a theoretical input for the elaboration of strategies to develop from the school, family and community ambit oriented to recover health, dignity and human condition (Fiorentino, 2008, p. 96) 
Resilience has been investigated by researchers under different approaches:

50s: Researchers focused their attention on how young people were able to survive and overcome adverse extreme situations such as poverty or abuse from a mentally sick parent, additional to the presence or absence of intrinsic qualities such as temper that acts with the social environment of a young person. (Anthony, 1987 quoted by Flores Olvera, 2013, p. 9)

80's: "studied the process and mechanism of protection involved emerging from resilience on a natural way. Arguing that resilience must be understood as a dynamic interaction between an individual and its environment." (Rutter, 1987 quoted by Flores Olvera, 2013, p.9; 2014, p.9).

Late 20th century: "researchers focused in actives on people, arguing that positive development, coping and resilience are present among those who have enough for both internal and external resources"(Lerner \& Benson, 2003 quoted by Flores Olvera, 2013, p.9; 2014, p.9).

21st century: There is a fourth wave on this decade that it is extending the discussion, arguing that the way in which we are understanding resilience currently is being is discursively negotiated and influenced by culture and the context in it. (Boyden \& Mann, 2005 quoted byr Flores Olvera, 2013, p.9; 2014, p.9). Besides focusing around the social resilience factor for helping others in cases such as pandemics like Covid19

Professionals that have been interested or integrated to resilience studies are "sociology, administration, social psychology, neuroscience, anthropology and genetics". However, "additionally there already are international organizations involved in the investigation and promotion of resilience, such as: UNICEF, CEPAL, World Bank, LAC and others on England and USA" (Flores Olvera, 2013, p. 10, 2014, p. 9).

\section{Part 3. Evolution and identified factors on resilience studies throughout time}

During the development of resilience studies there have been found a considerable number of related factors with it, among which vulnerable groups are highlighted, such as kids, teenagers, and women. It is also related with temper, family, community, environment, social support, self-esteem, dynamism and perseverance, adaptation, interaction, abilities, intelligence, context, Puig and Rubio (2013), do a line of time where they prove the concept of resilience and identify associated factors with it, just as shown in Table 1. 
Table 1. Conceptualization of resilience and associated factors

\begin{tabular}{|c|c|c|c|}
\hline Author & Year & Concept of Resilience & Identified factors \\
\hline $\begin{array}{l}\text { Werner and } \\
\text { Smith }\end{array}$ & 1982 & $\begin{array}{l}\text { "History of successful } \\
\text { adaptations on an } \\
\text { individual that has been } \\
\text { exposed to biological } \\
\text { factors of risk or stressful } \\
\text { events in life" (Puig and } \\
\text { Rubio, 2013). }\end{array}$ & $\begin{array}{l}\text { "Being a woman, } \\
\text { physically strong, socially } \\
\text { responsible, adaptable, } \\
\text { tolerant, oriented } \\
\text { towards concrete goals, } \\
\text { good communicators and } \\
\text { a good level of self- } \\
\text { esteem, helpful } \\
\text { environment and caring } \\
\text { in and out of the family" } \\
\text { (Puig and Rubio, 2013). }\end{array}$ \\
\hline Garmezy & 1991 & $\begin{array}{l}\text { "Capacity to recover and } \\
\text { maintain an adaptive } \\
\text { conduct after } \\
\text { abandonment and/or } \\
\text { initial incapacity when a } \\
\text { stressful event occurs" } \\
\text { (Puig and Rubio, 2013). }\end{array}$ & $\begin{array}{l}\text { "Temperament and } \\
\text { attributes (level of } \\
\text { activity, reflexive } \\
\text { capacity, cognitive } \\
\text { abilities, and } \\
\text { responsibility towards } \\
\text { others)" (Puig and Rubio, } \\
\text { 2013). } \\
\text { "Families (affection, } \\
\text { cohesion and the } \\
\text { presence of some adult } \\
\text { care)" (Puig and Rubio, } \\
\text { 2013). } \\
\text { "Availability of social } \\
\text { support (substitute } \\
\text { mother, interested } \\
\text { professor, help from an } \\
\text { organization, etc)" (Puig } \\
\text { and Rubio, 2013). }\end{array}$ \\
\hline Rutter & 1992 & $\begin{array}{l}\text { "Mix of social and } \\
\text { intrapsychic processes } \\
\text { that bring the possibility } \\
\text { of having a "sane" life } \\
\text { living on an "insane" } \\
\text { environment. These } \\
\text { processes would have a } \\
\text { place thought time, } \\
\text { giving lucky mixes }\end{array}$ & $\begin{array}{l}\text { "Being a woman, good } \\
\text { temperament, positive } \\
\text { school environment, self- } \\
\text { control, self-efficacy, } \\
\text { planning skills and a } \\
\text { close personal } \\
\text { relationship, warm and } \\
\text { stable at least with one }\end{array}$ \\
\hline
\end{tabular}




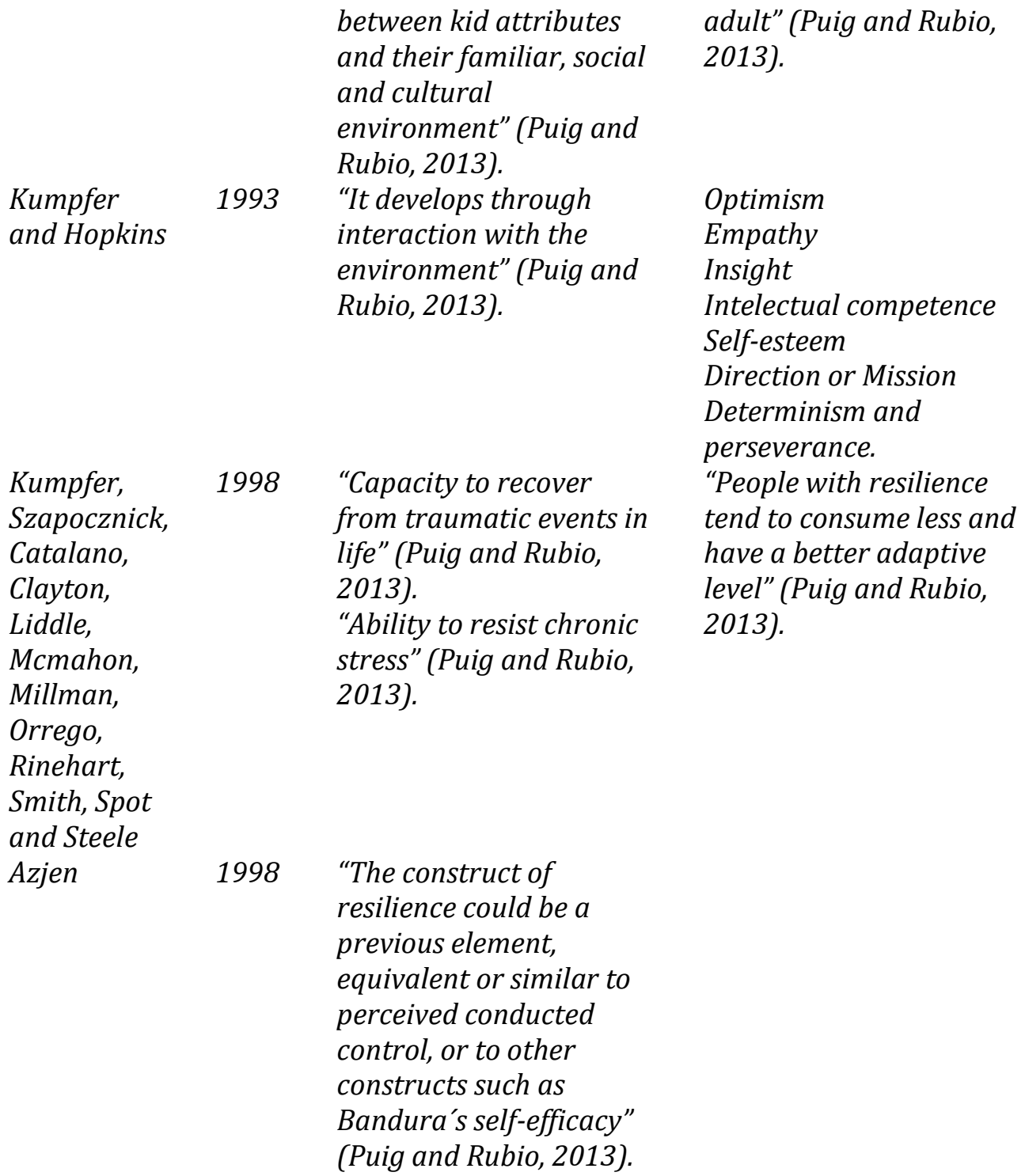

Braverman 1999 "Successful adaptation to exposition for significant stressors or other risks.

"We don't know if we should consider For him, resilience would resilience as a simple phenomenon, specific explain us why a person consumes or not in a from the individual or as a group of phenomena specific moment." (Puig and Rubio, 2013). that can be studied more independently in 
Masten

1999

"Feature relatively global from the personality that allows a person to a better adaptation to life" (Puig and Rubio, 2013).

Morrison, Storino, Robertson, Weissglas and Dondero Becoña

Luthar and Zelazo

Fergusson and Horwood

Fergus and Zimmerman

2005

2003 Rubio, 2013). not static" (Puig and

confrontment, ability to solve problems and selfregulating" (Puig and Rubio, 2013).

"Is should be considered as a process or phenomenon, not as a feature. It is modifiable "It explains the adaptation of people that have passed through tough or traumatic situations during their infancy" (Puig and Rubio, 2013).

"There are three models of resilience identified: compensatory, protective and challenging" (Puig and Rubio, 2013).

Grotberg
2006 "Capacity of the human being to face the adversities in life, overcome them and even being transformed by different areas" (Puig and Rubio, 2013). "Morrison, Storino, Robertson, Weissglas, Dondero" (Puig and Rubio, 2013).

\begin{abstract}
"It is going to depend on the interaction of the individual with his most immediate environment" (Puig and Rubio, 2013).
\end{abstract}

"The factors that take you to resilience are: intelligence and skill during problem solving" (Puig and Rubio, 2013).

"The community organization is a central element to produce resilience for those who are at risk" (Puig and Rubio, 2013).

Source of resilience:

I am

I have

I can

Triadic Model. 


\section{them" (Puig y Rubio, \\ 2013).}

Source: Puig and Rubio (2013, pp. 40-43).

\section{State of art in resilience. Studies of resilience at an international level}

There exists a multidisciplinary of studies related with resilience at an international level, this is why through Table 2, we will detail different approaches for these and the design for being able to have an analysis on more common studies about resilience.

Table 2. International studies of resilience

\begin{tabular}{|c|c|c|c|c|c|}
\hline $\begin{array}{l}\text { Author/Year } \\
\text { / } \\
\text { Country/Key } \\
\text { words }\end{array}$ & Focus & $\begin{array}{l}\text { Type of } \\
\text { investigat } \\
\text { ion }\end{array}$ & $\begin{array}{l}\text { Design } \\
\text { of } \\
\text { investiga } \\
\text { tion }\end{array}$ & $\begin{array}{l}\text { Instrume } \\
\text { nt }\end{array}$ & Results \\
\hline $\begin{array}{l}\text { Ríos, } \\
\text { Carrillo and } \\
\text { Sabuco } \\
(2012) \text {. } \\
\text { Murcia, } \\
\text { España. } \\
\text { Keywords: } \\
\text { Resilience } \\
\text { Burnout }\end{array}$ & $\begin{array}{l}\text { Resilience, } \\
\text { burnout } \\
\text { and } \\
\text { sociodemog } \\
\text { raphic } \\
\text { variables in } \\
\text { nursing } \\
\text { students. } \\
\text { Where the } \\
\text { levels of the } \\
\text { two first } \\
\text { variables } \\
\text { and the } \\
\text { variables of } \\
\text { the } \\
\text { sociodemog } \\
\text { raphic } \\
\text { samples } \\
\text { were } \\
\text { studied }\end{array}$ & $\begin{array}{l}\text { Quantitat } \\
\text { ive }\end{array}$ & $\begin{array}{l}\text { Transve } \\
\text { rsal/ } \\
\text { Descripti } \\
\text { ve/ } \\
\text { Correlati } \\
\text { onal }\end{array}$ & $\begin{array}{l}\text { Connor- } \\
\text { Davidson } \\
\text { Resilienc } \\
\text { e Scale } \\
\text { (CD- } \\
\text { RISC) }\end{array}$ & $\begin{array}{l}(+) \\
\text { resilienc } \\
\text { e }(-) \\
\text { emotion } \\
\text { al } \\
\text { fatigue } \\
\text { and } \\
\text { mayor } \\
\text { personal } \\
\text { fulfillme } \\
\text { nt } \\
\\
\text { Levels of } \\
\text { Burnout: } \\
28 \% \\
\text { emotion } \\
\text { al } \\
\text { fatigue } \\
19 \% \\
\text { cynicism }\end{array}$ \\
\hline $\begin{array}{l}\text { Molina, } \\
\text { (2013). } \\
\text { San Juan, } \\
\text { Argentina. } \\
\text { Keywords: } \\
\text { Resilience } \\
\text { Burnout }\end{array}$ & $\begin{array}{l}\text { Resilience } \\
\text { and } \\
\text { Burnout in } \\
\text { a public } \\
\text { hospital } \\
\text { from } \\
\text { Argentina }\end{array}$ & $\begin{array}{l}\text { Quantitat } \\
\text { ive }\end{array}$ & $\begin{array}{l}\text { Transve } \\
\text { rsal/ } \\
\text { Descripti } \\
\text { ve }\end{array}$ & $\begin{array}{l}\text { Connor- } \\
\text { Davidson } \\
\text { Resilienc } \\
\text { e Scale } \\
\text { (CD- } \\
\text { RISC). }\end{array}$ & $\begin{array}{l}(+) \\
\text { resilienc } \\
\text { e }(-) \\
\text { Levels of } \\
\text { Burnout } \\
(+) \\
\text { resilienc }\end{array}$ \\
\hline
\end{tabular}


in the

urgency

area

(relation

between

resilience

and

burnout

and the

association

of these

phenomeno

ns with

sociodemog

raphic

variables

and

lifestyles).

Castello Resilience

(2003).

from a

systemic

focus for

the

developmen

$\mathrm{t}$ of human

resources

and

organizatio

n. e (-)

Emotion

al

fatigue

and

(+)

Personal

fulfillme

nt

$\begin{array}{ll}\text { There } & (+) \\ \text { exist four } & \text { resilienc } \\ \text { bases to } & \text { e }(+) \\ \text { build } & \text { Adjustm } \\ \text { organizat } & \text { ent to } \\ \text { ional } & \text { the } \\ \text { resilienc } & \text { context } \\ \text { e, } & \text { and } \\ \text { accordin } & \text { insecurit } \\ \text { g to } & \text { y of the } \\ \text { Castello: } & \text { environ } \\ \text { Future } & \text { ment } \\ \text { goals } & (-) \\ \text { Confronti } & \text { Assimila } \\ \text { ng reality } & \text { tion of } \\ \text { explorati } & \text { total } \\ \text { on of } & \text { process, } \\ \text { meaning } & (+) \\ \text { Capacity } & \text { Treatme } \\ \text { of } & \text { nt } \\ \text { realizing } & \text { regressi } \\ \text { things } & \text { on and } \\ \text { with } & \text { reductio } \\ \text { elements } & \mathrm{n} \\ & \end{array}$


near our

approach

Mikulic and Fernández (2005) Buenos

Aires, Argentina.

Keywords:

Psychologic

al

Evaluation,

Strengths,

Children,

Teenagers

and

Resilience.

$\begin{array}{lll}\begin{array}{ll}\text { Philological } \\ \text { strength in }\end{array} & \begin{array}{l}\text { Quali- } \\ \text { Quantitat }\end{array} & \begin{array}{l}\text { Empirica } \\ \text { l and }\end{array} \\ \text { children } & \text { ive } & \text { descripti } \\ \text { and } & \text { Internati } & \text { ve } \\ \text { teenagers } & \text { onal } & \text { explorat } \\ & \text { sample } & \text { ory } \\ & 44 & \\ & \text { participa } & \\ \text { nts } & \\ \text { between } & \\ & 10 \text { and } & \\ & 18 \text { years } \\ & \text { old. }\end{array}$

Spirituality

and

resilience

and

Sánchez

(2007).

Cali, on abused

women that

file a

Colombia. complaint

Keywords: on their

Women situation of

health, relationship

violence in violence

relationshi

ps, abuse

women,

spirituality,

and

resilience situation $s$ of relations
Intervie Need of $\mathrm{w}$ inclusio

structure $n$ of the $\mathrm{d}$ to psycholo review gical strengths evaluati in on in the children context and of teenager children $\mathrm{s}$

and teenager $\mathrm{s}$

because it

provides them strength and sense of protecti on.

Quantitat ive

Correlati

Resilienc $(+)$ onal. e Scale (RS) of Spiritual sample

on purpose: (Wagnild ity (+) 100 and Resilienc e

between items.

18 and Spiritual

65 years perspecti old, that ve scale file a of Reed, complai with 10 nt on items. 


\section{hip \\ violence}

Source: Self-made elaboration from Ríos Rísquez (2012), Molina Collon (2013), Mikulic and Fernández (2006) and Canaval, González and Sánchez (2007).

\section{Studies of resilience in Mexico}

In Mexico there exist multiple studies about resilience, just as it is shown on Table 3:

Table 3. National studies of resilience

\begin{tabular}{|c|c|c|c|c|c|}
\hline $\begin{array}{l}\text { Author/Ye } \\
\text { ar }\end{array}$ & Focus & Method & $\begin{array}{l}\text { Scope of } \\
\text { Investigat } \\
\text { ion }\end{array}$ & $\begin{array}{l}\text { Instrumen } \\
\mathrm{t}\end{array}$ & Results \\
\hline $\begin{array}{l}\text { González } \\
\text { Arratia, } \\
\text { Valdez } \\
\text { Medina, } \\
\text { and } \\
\text { Zavala } \\
\text { Borja } \\
\text { (2008). } \\
\text { Tepic, } \\
\text { Nayarit. } \\
\text { México. } \\
\text { Keywords } \\
\text { : } \\
\text { Resilienc } \\
\text { e and } \\
\text { Resilienc } \\
\text { e } \\
\text { questiona } \\
\text { ry }\end{array}$ & $\begin{array}{l}\text { Resilienc } \\
\text { e in } 200 \\
\text { Young } \\
\text { Mexican } \\
\text { people }\end{array}$ & $\begin{array}{l}\text { Quantitati } \\
\text { ve }\end{array}$ & $\begin{array}{l}\text { Transvers } \\
\text { al }\end{array}$ & $\begin{array}{l}\text { Resilience } \\
\text { questionar } \\
\text { y } \\
\text { (Strength } \\
\text { and } \\
\text { personal } \\
\text { security of } \\
\text { González- } \\
\text { Arratia } \\
\text { and } \\
\text { ValdezMe } \\
\text { dina } \\
(2005) \text {. }\end{array}$ & $\begin{array}{l}(+) \\
\text { Resilienc } \\
\text { e on men } \\
\text { with } \\
\text { independ } \\
\text { ent } \\
\text { features, } \\
\text { on their } \\
\text { part } \\
\text { women } \\
\text { need an } \\
\text { external } \\
\text { backup to } \\
\text { be } \\
\text { resilient }\end{array}$ \\
\hline $\begin{array}{l}\text { Gaxiola, } \\
\text { González } \\
\text { and } \\
\text { Contreras } \\
(2012) \text {. } \\
\text { Hermosill } \\
\text { o, Sonora. } \\
\text { Keywords } \\
: \\
\text { Resilienc } \\
\text { e, }\end{array}$ & $\begin{array}{l}\text { Resilienc } \\
\text { e } \\
\text { influence, } \\
\text { goals, and } \\
\text { social } \\
\text { context in } \\
\text { the } \\
\text { academic } \\
\text { performa } \\
\text { nce of } \\
\text { high }\end{array}$ & $\begin{array}{l}\text { Quantitati } \\
\text { ve } \\
\text { Internal } \\
\text { variables: } \\
\text { goals and } \\
\text { resilience } \\
\text { External } \\
\text { variables: } \\
\text { risky } \\
\text { neighborh } \\
\text { ood and }\end{array}$ & $\begin{array}{l}\text { Transvers } \\
\text { al }\end{array}$ & $\begin{array}{l}\text { The scale } \\
\text { about } \\
\text { goals for } \\
\text { teenagers } \\
\text { (Sanz de } \\
\text { Acedo, } \\
\text { Ugarte and } \\
\text { Lumbrera } \\
\text { s, 2003). } \\
\text { Inventory } \\
\text { of }\end{array}$ & $\begin{array}{l}(+) \\
\text { resilience } \\
(+) \\
\text { academic } \\
\text { performa } \\
\text { nce } \\
\text { predictio } \\
\text { n, during } \\
\text { school } \\
\text { goals. }\end{array}$ \\
\hline
\end{tabular}




$\begin{array}{lll}\begin{array}{l}\text { Academic } \\ \text { performa }\end{array} & \begin{array}{l}\text { school } \\ \text { nce and }\end{array} & \begin{array}{l}\text { risky } \\ \text { young }\end{array} \\ \text { High } & \text { Mexicands. } & \\ \text { School } & \text { people). } & \end{array}$

$\begin{array}{llll}\begin{array}{l}\text { Palomar, } \\ \text { Matus }\end{array} & \begin{array}{l}\text { What is } \\ \text { resilience }\end{array} & \begin{array}{l}\text { Quantitati } \\ \text { ve }\end{array} & \begin{array}{l}\text { Transvers } \\ \text { al }\end{array} \\ \text { and } & \text { of } & & \\ \text { Victorio } & \text { extreme } & & \\ \text { (2013). } & \text { poverty } & \\ \text { Urban } & \text { from the } & \\ \text { areas } & \text { center of } & \\ \text { near the } & \text { Mexico } & \\ \text { Federal } & \text { made of? } \\ \text { District. } & \text { (sample } & \\ & 913 & \\ & \text { people) }\end{array}$

$\begin{array}{llll}\begin{array}{l}\text { González- } \\ \text { Arratia, }\end{array} & \begin{array}{l}\text { Knowing } \\ \text { the }\end{array} & \begin{array}{l}\text { Quantitati } \\ \text { ve }\end{array} & \begin{array}{l}\text { Transvers } \\ \text { al }\end{array} \\ \text { Valdéz- } & \text { features } & \\ \text { Medina, } & \text { of } & \\ \text { Pasa- } & \text { resilience } & \\ \text { Flores } & \text { in } & \\ \text { and } & \text { children } & \\ \text { González- } & \text { in a } & \\ \text { Escobar } & \text { poverty } & \\ \mathbf{( 2 0 0 9 ) .} & \text { situation } & \\ \text { Mexico } & \text { of a rural } & \\ \text { State } & \text { comunity } & \\ \text { Keywords } & (100 & \\ : & \text { children, } & \\ & 50 \text { men }\end{array}$

Resilience

(IRES)

(Gaxiola,

Frías,

Hurtado,

Salcido

and

Figueroa

2011).

$\begin{array}{ll}\text { Connor- } & (+) \\ \text { Davidson } & \text { Strength: } \\ \text { Resilience } & \text { Locus } \\ \text { Scale } & \text { internal } \\ \text { (Connor } & \text { control, } \\ \text { and } & \text { motivatio } \\ \text { Davidson, } & \text { n till } \\ \text { 2003). } & \text { achievem } \\ & \text { ent and } \\ & \text { direct } \\ & \text { confronti } \\ & \text { ng }\end{array}$

$(+)$

Confronti

ng of

adverse

condition

$\mathrm{S}$

Resiliance High level

questionar of

$y \quad$ resilience

(González at the

Arratia, three

Valdez, dimensio

and ns of the

Salazar instrume

2006) (32 nt:

replies). 1 .

internal

protectiv

e factors

2.

external 


$\begin{array}{lll}\text { Resilienc } & \text { and } 50 & \text { protectiv } \\ \text { e, } & \text { women) } & \text { e factors } \\ \text { Poverty } & & 3 . \\ \text { and } & & \text { empathy }\end{array}$

\section{Children}

Source: Self-made elaboration from the literature (Gaxiola Romero et al., 2012; González Arratia López Fuentes et al., 2008; González-Arratia López et al., 2012; Salgado Arteaga et al., 2018).

\section{Merton's Model: The Pygmalion effect}

We individuals coexist day to day with other people and we need their trust and acceptance, it is because of this that Merton (1964) named Pygmalion effect to obtained results on the behavior of an individual, derived from the expectations and opinion from other people. This means that, the individual will obtain mediocre results, if other people treat him with mistrust and devalue. Meanwhile, if this situation is opposite, and the individual is treated with trust and value, then the results of the individual work would increase drastically. Coming from Merton contributions (1964), it is detached that the trust that other people have on an individual, will reinforce it to achieve goals with a mayor complexity and this is very important, given that all the individuals need in one way or another is support and acceptance of others to be able to potentiate our capabilities and hidden abilities.

In the world we are living on we face a lot of challenges; therefore, a resilient culture must be constructed, in which values, respect, dignity, triumph, and happiness are always available. Resilience isn't static, it is dynamic and if it isn't feed, it can even die; it is true that when an individual is born it is resilient, but if this resilience doesn't have a continuous feedback it tends to die and turn itself in an opposite phenomenon called asilient anomie. It is very important to have a "positive vision for the future of mankind" (Flores Olvera, 2013, p. 16), however, this is a hard task from all of the contexts in which the individual develops itself. High executives, leaders, teachers, instructors, and bosses must focus in creating a chain effect in resilience constructing and not only individual, but social in ways of strength for facing tough situations. In the world there exists: "pessimism, depression, suicide, anxiety, posttraumatic stress disorder, drug abuse, violence, this is nothing new or unknown among employees, students and families from Mexico" (Flores Olvera, 2013, p. 16), this is why asilient anomie must be eliminated and we must promote the strength resilience to build an environment of peace, wellness, mental health and productivity in every context where the individual interacts.

\section{Shakespeare's Principle Model}

When people have positive and negative aspects that a daily effect on them, in one way or another, this phenomenon is known as Shakespeare's principle and it refers to the actions both negative and positive that increase or decrease levels of resilience 
from individuals (Flores Olvera, 2013) this effect is known as filling or empting an internal tank for a person. Depending on their age is how can someone fill or empty Shakespeare's tank, and it is because the importance of knowing what activities help us to feed back the resilience levels on people to strength them on environments where they are developed.

\section{Plan B}

Now we detail the actions from the government or national, regional, and global leaderships that could be done in an articulated way:

Create comprehensive programs about friendship.

Create comprehensive programs about teamwork, group activities, the feeling of belonging in a social group, the celebrating the achievement of another person, listening to others, to actively participate in social events not only from work if not from citizens; if these are efficient they will have positive effects on citizens such as high levels of security, self-esteem, optimism, hope, happiness and creativity.

Comprehensive programs that encourage in an individual and positive way to elevate individual resilience levels: practicing sports, coexist with nature and other people, having an active social life, having presence on social networks with the intention of receiving positive actions from other people, having at least one clear and precise goal in life, planning short or medium term goals, having osseous and fun times (camping, board games, going to parties, healthy activities, singing, hobbies), having a pet, being thankful and giving others positive actions.

Create a program to release data bases or payment repositories where they keep more recent investigations about pandemics for all the academics to be popularizers in every part of the country for educating during pandemics.

Integrate a subject or seminary on curriculums of elementary, middle, and high schools and colleges to be transversal for studying.

Append the organizational learning Theory to study the phenomenon of resilience in human resources on organizations in every postgraduate existing in the world.

Build a model of resilience culture specifically for future pandemics.

Create recruitment and selection models for all the public and private organizations it the world that from the beginning start to apply instrument for measuring their capacity of resilience, and from there.

Create an institutional entertaining program.

Create in a permanent way investigation programs that not only study from the medical perspective, if not organizational and administrative, the impact of pandemics on organizations. 


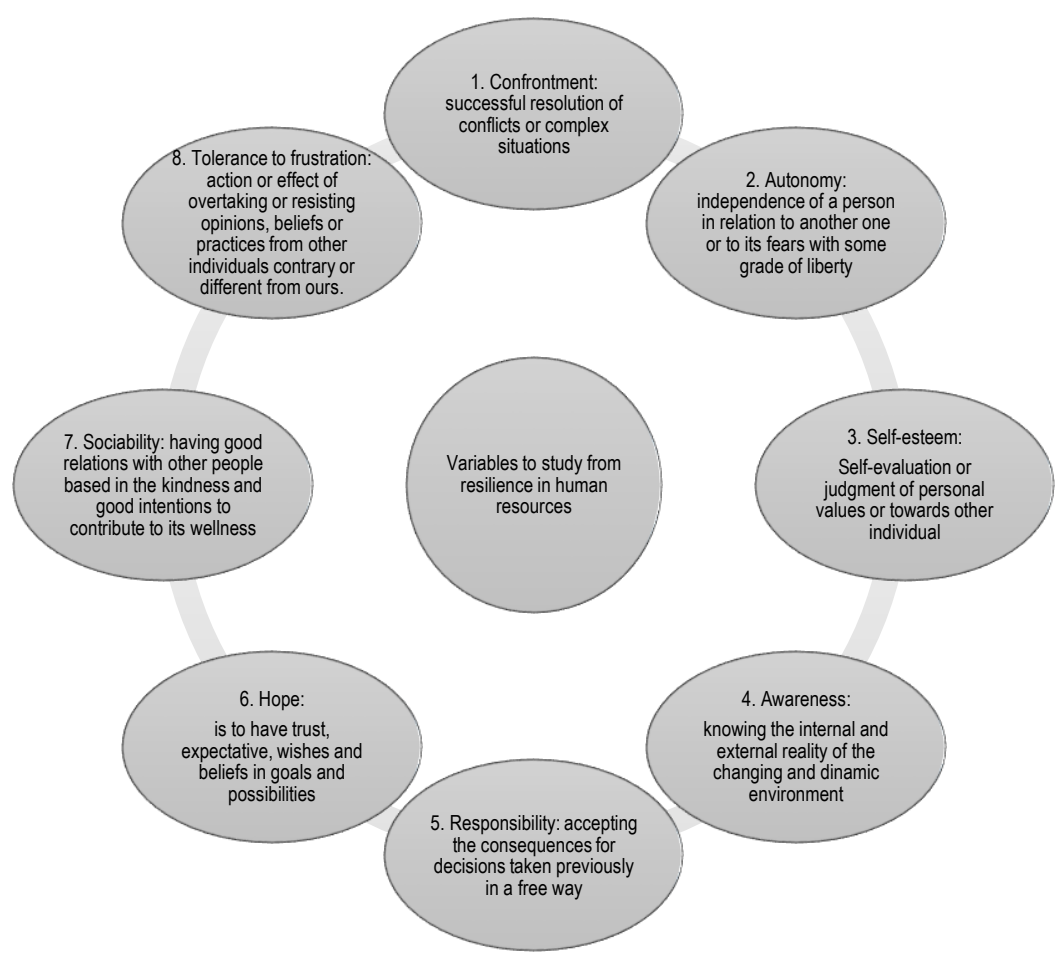

Figure 3. Methodological model for studying social resilience. Source: self-made elaboration from Flores Olvera (2014).

\section{Conclusion}

The present pandemic scenario in the world (2020), is a challenge and threatens the human resistance process in every way; physical and mental. This threat affects eight dimensions in the life of a human being: confrontment, autonomy, self-esteem, awareness, responsibility, hope, sociability, tolerance to frustration and life. But, do private and public organizations are aware of these dimensions? Every, and each of them are the resilient base for the human towards adverse situations. Given this, we expose the results found in the literature:

In this Covid-19 situation in many countries, such as Mexico, the answer was to send the population to quarantine and the strategy known as "sana distancia" as better tools to face it; quarantine has been used a long time ago as tool to prevent the possible spread of diseases transmissible among the population.

About the costs to consider regarding this strategy (obligatory on quarantine): economic decay, as a consequence, millions of people lost their jobs; serious feelings of anguish, frustration and violence against people that live in their environment (sons, couples, parents), psychological effects of high prevalence such as anguish; 
negative psychological effects, including symptoms of posttraumatic stress, confusion and anger. High duration stressing factors like: fear of virus exposition, contagion, disappointment, tedium, alimentary insecurity, inadequate information, financial loss.

Lack of strategies and projects for resilient strength of people.

Deficient information perception and sometimes misleading from part of authorities from public health or government. Uncertainty was also present from part of officials from health and government about the severity of the pandemic.

The pandemic has put in evidence the deficiency of the scientific system in the world and even more in Mexico. These important crises tend to reveal hidden norms in the scientific system, making well-known practices from science public. The coronavirus outbreak (COVID-19) in Mexico and the world exposes an uncomfortable truth: that the actual academic communication system does not satisfy all the needs for science and society.

Two inefficiencies are revealed in the investigation system: the predetermined value of closed science and the excessive emphasis on elite publishing, only in English, independently from the context and the consequences of the research. In Mexico's case, this is not weird, due to the political system collapsing, medical staff without the knowledge and experiencing on this virus treatment made this sector to have $17 \%$ of infected people among managers, nurses, medics and even administrative staff (Health Secretary of Mexico, 2020) and they infected their families and friends just as a snowball.

Obligatoriness proposed by the declaration of the Wellcome Trust about dominant editors like Elsevier, Springer Nature and, Taylor \& Francis was necessary, and as funders and academic societies; to compromise to make every investigation and data about the outbreak public immediately: on preprints repositories for those articles that haven't been checked by pairs yet, and on magazine platforms for those articles that were already checked. Signatories from the Wellcome Trust agreed on keeping these principles not only for the actual outbreak but for every other situation were "there in a significant benefit for public health by guaranteeing that data is shared on a wide and quick way" (Carr, 2020).

This is a positive step, but not enough to satisfy public needs, because the only thing it did, at least for Mexico, was to liberate and give open access to collections that doesn't have anything to do with the problem; which limits the ability to inform and aware people form the academic ambit at least and work as expositors with collaborative tools to reach more citizens from countries and the world.

A scientific community call must be done (editors, funders, and society) for maintaining true to its words. The statement from The Wellcome Trust is incorrect: it is necessary to quickly share the investigation for saving lives and informing the 
public. Even though we applaud the job that is being done in this crisis, we hope for this moment to work as a catalyst for change.

The documents and chapters from books that have been released over this action represent just a small portion of the literature available about coronavirus. According to the Web of Science (WoS), there have been 13,818 articles published about the coronavirus topic since the end of the 1960 decade. More than the half $(51.5 \%)$ of these articles remain closed for the public to read.

Publication incentives are the other controversial element revealed by the actual outbreak. During the last decade, authorities and Chinese institutions, such as the ones in many other countries, have offered a financial direct reward based on the magazine in which researchers publish their work, with the implicit objective to put in a better position their institutions on international classifications. Invariably, publishing on these magazines implies to adjust to a frank language (English) and to publish about topics that matter to most of the guardians of these magazines, that are disproportionately from western countries

Meanwhile, a larger diffusion to the scientific community is a more important objective; it should not be at the expense of diffusion to local communities, particularly to those who have a direct connection to the study scope. Due to the payment barriers and the use of English, international magazines tend to be inaccessible to those who are on the first global line of proposing medical attention and elaborating health norms, especially on crisis times. The only researchers that have possibilities of economic support to pay these articles are the ones on hard science and only a small group.

The actual coronavirus outbreak exemplifies this efficiency. In late 2019, the Chinese Center for Control and Decease Prevention (CCDCP) sent a group of experts to Wuhan to recover data about the virus. This was almost three weeks after the first patient presented symptoms and right after the news of human-human transmission on social networks by eight different medics from Wuhan (posteriorly they were accused by police). Researchers analyzed data and the presented their results, including a verification of human-human virus transmission to high-prestige magazines from the west, such as The Lancet and The New England Journal of Medicine (NEJM), published on January 24th and 29th respectively. On January 20th it was published a public statement, recognizing the transmission form human to human.

In response to this, the Chinese government stipulated that financed projects about coronavirus, including the ones with new initiative 1.5M from the National Science Foundation of China (NSFC), should be published in local Chinese magazines instead of international ones and the emphasis should be for controlling the virus and saving lives. This is something that most of the countries never did, and even less in Latin America. 
The signatories of the declaration from Wellcome Trust must extend their principles to cover all their practices: make the investigation to be available immediately and incentivize scientific communication to all the people who are interested. The scientific answer to Covid-19 has proven some of the benefits for opening the scientific system.

The review from the State of Art for the impact of Covid-19 does not show a resilient program at all as alternative, neither as plan B for future world pandemics. Fairly.

According to verified national and international investigations, resilience has been brought, but focused around kids, young people, and women in a situation of vulnerability, poverty, violence, and educational context, but not for phenomenon like pandemics, Covid-19. More recent studies focused around resilience have been accomplished on an international ambit with a quantity focus and a correlational scope.

Thus, there is the necessity for creating a global model, International, regional, or local of resilience for citizens. It is affirmed that it is the capacity for recovering and maintaining and adaptive behavior after being abandoned or the initial incapacity to start an stressing event, it is true people with less capacity for recovering or maintaining and adaptive behavior are the ones that have less economic or material resources. It is June $28^{\text {th }}, 2020$, and the present effects from Covid-19 exist, people are still getting infected and dying, and new psychological effects are being born. What awaits us without a Plan B? What awaits us without a Resilient Plan?

The impact of the pandemic remains among us, what remains to come is the subjective and intersubjective impact on the human being, and the intervention of organizations, public and private, is not notable.

\section{References}

[1] Amar Amar, J., Martínez González, M., \& Utria Utria, L. (2013). New approach to health considering the resilience. Revista Salud Uninorte, 29(1), 124-133. http://www.scielo.org.co/scielo.php?script=sci_abstract\&pid=S0120$55522013000100014 \& \operatorname{lng}=e n \& n r m=i s o \& t \operatorname{lng}=e s$

[2] Anthony, E. J. (1987). Risk, vulnerability, and resilience: An overview. The invulnerable child, 3-48.

[3] Banco Mundial. (2018). Indicadores del desarrollo mundial—Google Public Data Explorer.

https://www.google.com/publicdata/explore?ds=d5bncppjof8f9_\&met_y=s p_pop_totl\&idim=country:MEX\&hl=es\&dl=es

[4] Barbisch, D., Koenig, K. L., \& Shih, F.-Y. (2015). Is There a Case for Quarantine? Perspectives from SARS to Ebola. Disaster Medicine and Public Health Preparedness, 9(5), 547-553. https://doi.org/10.1017/dmp.2015.38 
[5] Bedford, J., Enria, D., Giesecke, J., Heymann, D. L., Ihekweazu, C., Kobinger, G., Lane, H. C., Memish, Z., Oh, M.-D., Sall, A. A., Schuchat, A., Ungchusak, K., Wieler, L. H., \& WHO Strategic and Technical Advisory Group for Infectious Hazards. (2020). COVID-19: Towards controlling of a pandemic. Lancet (London, England), 395(10229), 1015-1018. https://doi.org/10.1016/S0140-6736(20)30673-5

[6] Boyden, J., \& Mann, G. (2005). Children's Risk, Resilience, and Coping in Extreme Situations. En Handbook for Working with Children and Youth: Pathways to Resilience across Cultures and Contexts (pp. 3-26). SAGE Publications, Inc. https://doi.org/10.4135/9781412976312

[7] Braunack-Mayer, A., Tooher, R., Collins, J. E., Street, J. M., \& Marshall, H. (2013). Understanding the school community's response to school closures during the H1N1 2009 influenza pandemic. BMC Public Health, 13(1), 344. https://doi.org/10.1186/1471-2458-13-344

[8] Canaval, G. E., \& Sánchez, M. O. (2007). Espiritualidad y resiliencia en mujeres maltratadas que denuncian su situación de violencia de pareja. Colombia Médica, 38, 7.

[9] Carr, D. (2020). Sharing research data and findings relevant to the novel coronavirus (COVID-19) outbreak. Wellcome. https://wellcome.ac.uk/coronavirus-covid-19/open-data

[10] Desclaux, A., Badji, D., Ndione, A. G., \& Sow, K. (2017). Accepted monitoring or endured quarantine? Ebola contacts' perceptions in Senegal. Social Science \& Medicine, 178, 38-45. https://doi.org/10.1016/j.socscimed.2017.02.009

[11] Fiorentino, M. T. (2008). La Construcción De La Resiliencia En El Mejoramiento De La Calidad De Vida Y La Salud. Suma Psicológica, 15(1), 95113. https://www.redalyc.org/articulo.oa?id=134212604004

[12] Flores Olvera, D. (2013). La resiliencia nómica mejor ambiente educativo, familiar, escolar y comunitario. Una nueva realidad de la familia (Primera). Instituto Internacional de Investigación para el Desarrollo.

[13] Flores Olvera, D. (2014). La Resiliencia nómica. Un mejor desempeño en el afrontamiento de adversidades más exigentes. Para lograr una vida más satisfactoria. (Primera). Instituto Internacional de Investigación para el Desarrollo.

[14] Garmezy, N. (1991). Resilience in children's adaptation to negative life events and stressed environments. Pediatric Annals, 20(9), 459-460, 463466. https://doi.org/10.3928/0090-4481-19910901-05 
[15] Gaxiola Romero, J. C., González Lugo, S., \& Contreras Hernández, Z. G. (2012). Influencia de la resiliencia, metas y contexto social en el rendimiento académico de bachilleres. Revista electrónica de investigación educativa, 14(1), 165-181.

[16] González Arratia López Fuentes, N. I., Valdez Medina, J. L., \& Zavala Borja, Y. C. (2008). Resiliencia en adolescentes mexicanos. Enseñanza e investigación en psicología, 13(1).

[17] González-Arratia López, N. I., Valdez Medina, J. L., Oudhof van Barneveld, H., \& González Escobar, S. (2012). Resiliencia y factores protectores en menores infractores y en situación de calle. Psicología y salud, 22(1), 49-62.

[18] Hawryluck, L., Gold, W. L., Robinson, S., Pogorski, S., Galea, S., \& Styra, R. (2004). SARS Control and Psychological Effects of Quarantine, Toronto, Canada. Emerging Infectious Diseases, 10(7), 1206-1212. https://doi.org/10.3201/eid1007.030703

[19] Kotliarenco, M. A., Cáceres, I., \& Fontecilla, M. (1997). Estado de arte en resiliencia. Organización Panamericana de la salud.

[20] Lerner, R. M., \& Benson, P. (Eds.). (2003). Developmental Assets and AssetBuilding Communities: Implications for Research, Policy, and Practice. Springer US. https://doi.org/10.1007/978-1-4615-0091-9

[21] Manuell, M.-E., \& Cukor, J. (2011). Mother Nature versus human nature: Public compliance with evacuation and quarantine. Disasters, 35(2), 417442. https://doi.org/10.1111/j.1467-7717.2010.01219.x

[22] Maslach, C., Schaufeli, W. B., \& Leiter, M. P. (2001). Job Burnout. Annual Review of Psychology, 52(1), 397-422.

https://doi.org/10.1146/annurev.psych.52.1.397

[23] Meneghel, I., Salanova, M., \& Martínez, I. M. (2013). El camino de la Resiliencia Organizacional-Una revisión teórica. 31(2), 13-24. http://www.want.uji.es/wp-content/uploads/2017/02/2013_MeneghelSalanova-Mart\%C3\%ADnez.pdf

[24] Merton, R. K. (1964). Anomie, Anomia and Social Interaction. Contexts of Deviant Behavior. Free Press.

[25] Mihashi, M., Otsubo, Y., Yinjuan, X., Nagatomi, K., Hoshiko, M., \& Ishitake, T. (2009). Predictive factors of psychological disorder development during recovery following SARS outbreak. Health psychology : official journal of the Division of Health Psychology, American Psychological Association, 28(1), 91-100. https://doi.org/10.1037/a0013674 
[26] Mikulic, I. M., \& Fernández, G. L. (2006). Importancia de la evaluación psicológica de las fortalezas en niños y adolescentes Adolescents and children strengths psychological assessment importance. Anuario de Investigaciones, 13(unknown), 279-287.

[27] Molina Collon, M. D. (2013). Resiliencia y burnout en trabajadores de urgencias de un hospital público de San Juan, Argentina. V Congreso Internacional de Investigación y Práctica Profesional en Psicología, 4.

[28] Pellecchia, U., Crestani, R., Decroo, T., Bergh, R. V. den, \& Al-Kourdi, Y. (2015). Social Consequences of Ebola Containment Measures in Liberia. PLOS ONE, 10(12), e0143036. https://doi.org/10.1371/journal.pone.0143036

[29] Puig, G., \& Rubio, J. L. (2013). Manual de resiliencia aplicada. Profesorado, Revista de Currículum y Formación del Profesorado, 17(2), Article 2. https://recyt.fecyt.es/index.php/profesorado/article/view/42100

[30] RAE-ASALE. (2020). Resiliencia. En «Diccionario de la lengua española»Edición del Tricentenario. https://dle.rae.es/resiliencia

[31] Reynolds, D. L., Garay, J. R., Deamond, S. L., Moran, M. K., Gold, W., \& Styra, R. (2008). Understanding, compliance and psychological impact of the SARS quarantine experience. Epidemiology and Infection, 136(7), 997-1007. https://doi.org/10.1017/S0950268807009156

[32] Ríos Rísquez, M. I., Carrillo García, C., \& Sabuco Tebar, E. (2012). Resiliencia y Síndrome de Burnout en estudiantes de enfermería y su relación con variables sociodemográficas y de relación interpersonal. International Journal of Psychological Research, 5(1), 88-95. https://dialnet.unirioja.es/servlet/articulo?codigo $=5134686$

[33] Rubin, G. J., \& Wessely, S. (2020). The psychological effects of quarantining a city. BMJ, 368. https://doi.org/10.1136/bmj.m313

[34] Rutter, M. (1987). Psychosocial resilience and protective mechanisms. American journal of orthopsychiatry, 57(3), 316-331.

[35] Salgado Arteaga, A., Salgado Arteaga, D. B., Pérez Mayo, A. R., \& Vallejo Trujillo, L. S. (2018). Resilience and Organizations: A State of the Art. Journal of Human Resource and Sustainability Studies, 6(2), 194-209. https://doi.org/10.4236/jhrss.2018.62037

[36] Secretaría de Salud. (2020, junio 21). COVID-19 Tablero México. COVID - 19 Tablero México. http://datos.covid-19.conacyt.mx/index.php

[37] Sprang, G., \& Silman, M. (2013). Posttraumatic stress disorder in parents and youth after health-related disasters. Disaster Medicine and Public Health Preparedness, 7(1), 105-110. https://doi.org/10.1017/dmp.2013.22 
[38] WHO. (2020, junio 22). WHO Coronavirus Disease (COVID-19) Dashboard. World Healt Organization. https://covid19.who.int/ 